\section{Migration and Immigrants in Social Studies Textbooks (Turkey and US Sample)}

\author{
Hakan Dündara, ${ }^{*}$, Elizabeth Kenyon ${ }^{b}$
}

$\begin{array}{ll}\text { Received: } & 7 \text { December } 2019 \\ \text { Revised: } \quad 23 \text { February } 2020 \\ \text { Accepted: } \quad 3 \text { March } 2020 \\ \text { ISSN: 1307-9298 } \\ \text { Copyright @ IEJEE } \\ \text { www.iejee.com }\end{array}$

DOI: 10.26822/iejee.2020459465

\begin{abstract}
In this research, it is discussed how migration and immigrant issues were examined in a comparative way in textbooks in Turkey and the United States. For this purpose, Life Studies and Social Studies textbooks of both countries were determined and of how migration and immigrants in terms were handled comparatively in these books. This research is a descriptive study. Document analysis technique was used for data collection. Both countries are trying to present the concepts of migration and immigrant under the student acquisition and competence related to cultural differences in curriculum. Overall, is the knowledge is given of what kind of migration and immigrant in Turkey's textbooks at the same time it is seen that contact with immigrants and tried to give the idea of integrating them into society to help them streamline their behalf. In the US textbooks, it is seen that the concepts of migration and immigrant are given meaning and the difficulties faced by immigrants are emphasized. More emphasis on immigrants is that they can achieve significant success as a US citizen and maintain their culture comfortably.
\end{abstract}

Keywords: Migration, Immigrant, Textbook, Problems of Immigrants

\section{Introduction}

Migration, which is as old as the history of humanity, is a topic that is recently at the forefront of the whole world. Millions of people have had to migrate for better living conditions due to war and chaos in different parts of the world, especially in the Middle East (Gür, 2017). In addition, individuals and families migrate for purposes of their careers in the increasingly globalized economy. Migration can be defined as a geographic displacement event in which people relocate either temporarily or permanently (Bardsley \& Hugo, 2010; Dubey \& Mallah, 2015; Hunter, 2005; Kyaing Kyaing, 2013; Lundquist \& Massey, 2005). According to the Migration Terms Dictionary of the International Organization for Migration (IOM) migration is formed by crossing an international border or moving within the state. The reason, structure and duration of displacement are all important factors. To think that migration is just an act of displacement is a deficient definition for migration. Migration can be explained by the wishes of people who want a higher standards of living and to realize their hopes and go in different directions for a permanent or temporary change (Aksoy, 2012, p. 293). This migration process consists of displaced persons, refugees and economic migrants (IOM, 2013, p. 22).

Using the United Nations International Migrant report, which measures migration every five years, it is possible to understand the increasing importance of the migration process on global systems. If we look at the change between 2000 and 2015 we see that migration has a very important place in a globalized world. While the number of global migrants was 173 million in 2000, it reached 191 million in 2005, 222 million in 2010 and 244 million in 2015 (UN-International Migration Report, 2015, p. 5). When the above figures are examined, it can be said that the number of international migrants has increased significantly and approximately one in thirty people are migrants around the world. The process of migration has become easier with globalization and technology revolution. However, one of the most important reasons for migration is the desire to escape from the environments of war and to better living conditions.
Beacuse issues of migration are often a contentious political topic, it is important that citizens be well informed as to the causes of migration and the various challenges and opportunities migrants face. Understanding the broader context of migration is crucial in these often vicious debates. That understanding should start at a young age. Research shows that prejudices begin to develop at a very young age (Van Ausdale \& Feagin, 2001) and so they must be combated through knowledge and understanding.

\section{Migration, Migration Types and Immigrants}

Migration is one of the most important social developments of our age; both resulting from and contributing to globalization. Migration is generally a tool for improving economic and social conditions as well as being considered as a result of economic and social development (Castles, 2000, p. 269; Dubey \& Mallah, 2015; Kyaing-Kyaing, 2013; Suarez-Orozco, 2001). Migration is often categorized into different categories on the basis of the immigrant's location and motivation of the immigrant (Skeldon, 1997, p. 57). In addition, key factors such as geographical, legal, political, methodological, temporal as well as the place of birth, citizenship, place of residence and length of stay differentiate the type of migration (IOM, 2018; Şahin, 2001, p. 59; Yılmaz, 2014, p. 1686). It is possible to classify migration according to some criteria, internal and external / international based on area characteristics, temporary and permanent according to time criterion, individual migration and mass migration according to size, voluntary or forced migration according to the reason and legal status criterion (legal) and irregular (illegal) (IOM, 2009, p. 27).

Mobility, which is carried out by displacement within the country and which does not affect the population of the country by changing the population ratio of regions or provinces, can be defined as internal migration (Koçak \& Terzi, 2012). External migration, in other words, is defined as international migration, whereby individuals are temporarily or permanently separated from their motherland or from a country where they are permanently resident in order to settle in another country (IOM, 2009, p. 59). There is a distinc- 
tion between legal and illegal migration, or documented and undocumented, where persons or communities are outside their national boundaries, depending on whether or not they go through official channels and visa processes (Emin, 2018). Migration in accordance with their country of origin, country of transit, and the legal procedure for the country of migration is expressed as legal migration. Completing this process by illegal means, in other words, making illegal entry into a country or working illegally is defined as irregular migration (IOM, 2009, p. 21).

Another distinction within migration is individual and mass migrations. Individual migration is the migration that people perform as individuals for a variety of personal reasons (political, economic, education, etc.). Mass migration means that societies or people living in a particular region are displaced for various reasons. The mass migration action can be defined as the movement of a large number of people in an irregular group through an international border at a given time and, as a result, a foreign influx to another country (Akıncl et al., 2015; Emin, 2018). The migration of people in order to survive in other regions and countries by abandoning their places of residence is called continuous migration and can be made both voluntarily and involuntarily. Temporary migrations are; migration to any territory or country for a specific reason at a given time that are short term (Koçak \& Terzi, 2012, p. 10; Naz, 2015, p. 20)

Forced migration is when people have to leave their homeland because of various reasons that are outside their control and often against their wishes. Volunteer migrations are migration based on the wishes of individuals for better living conditions and new opportunities (Taş \& Özcan, 2013, p. 289). Immigrants in mass and forced migration are more likely to have refugee status. According to the 2018 World Migration Report, it is estimated that in 2015 the number of international migrants was 244 million, which corresponds to $3.3 \%$ of the world's population. Internal migration is much more than external migration, and more than 740 million people migrate within their own country, according to IOM (IOM, 2018). There are also 22.5 million refugees registered by the United Nations High Commissioner for Refugees (UNHCR) at the end of 2016 (IOM, 2018)

\section{Challenges Facing Migrants}

There are many challenges faced by immigrants. It is possible to differentiate these problems into different categories such as economic, health, cultural, social and educational. Immigrants are generally different in terms of social, cultural, linguistic and religious aspects from the country that accepts them (Castles \& Miler, 2008, p. 18). In particular, language differences can make life particularly challenging for immigrants. As immigrants lose the function of their own language in the society they live in, it can have negative emotional and psychological impacts (Erol \& Ersever, 2014, p. 53). In the studies that explore the various challenges new immigrants face, legal, economc, employment, health, nutrition and education are among the most serious. (Hall \& Cuellar, 2016; IOM, 2013; Landale, Thomas, \& Van Hook, 2011; Tienda \& Haskins, 2011 Zimmerman, Kiss, \& Hossain, 2011). Garrett (2006) lists the most common problems faced by migrants in America: - Problems with the education system, - Business opportunities and housing problems, - isolation and - prejudice, cultural incompetence and discrimination. Garrett in the same study; he says that the difference in the pronunciation of an immigrant implies a better life.

Rubinstein-Avila (2017) described migration as a long-term process and highlighted that migrants will face many different problems by pointing out that crossing a national border is only the beginning for immigrants. One of the biggest problems faced by the immigrants is accessing appropriate education for their children and families. When accessing appropriate education is a challenge, students often experience language problems, low academic achievement, behavior problems and school drop out (Leeman \& Ledoux, 2003; Morrice, Shan, \& Sprung, 2017; Tienda \& Haskins, 2011; Rubinstein-Avila, 2017; Portes \& Rivas, 2011; Worbs, 2003,). Rubinstein-Avila (2017) pointed out that the number of immigrant students on a global scale increases every day and that one in four children in the United States was an immigrant, a refugee, or a US born immigrant child, and that teachers and educators should be sensitive about this issue and they should design their teaching to meet the needs of these students. It is also important to know that immigrant children around the world are a growing segment of the school population. Therefore, political initiatives and funding decisions need to be tailored to the specific needs of migrant children. Because if the migratory children are better served today, they will also contribute to the future prosperity of the countries (Suarez-Orozco, 2001, p. 155-156).

Migrants have the power to influence their communities directly and indirectly. The policies developed for immigrants will not only facilitate the adaptation of migrants to the society they live in, but will also provide an opportunity for the country that accepts migration to create added value in all areas, especially in economic and cultural areas. The policies developed during the integration process of migrants are implemented through formal and non-formal education processes. In this process, it is important in materials used as much as educational environments. And with these materials, textbooks play an important role in terms of the processes of adaptation and effective citizenship skills of immigrants, migrants and other students especially in schools. In this research, it is discussed how migration and immigrant issues were examined in a comparative way in textbooks in Turkey and the United States.

\section{Different Migration Contexts: Turkey and the United States}

The geographic location of the United States and Turkey play an important role in the number of migrants that enter each country each year and also the type of migrant. In general, most migrants in the United States come for educational and economic opportunity, while the majority in Turkey are refugees fleaing war-torn countries. This is particularly true in the past decade due to the çivil war in Syria. According to a 2016 report there were about 1.6 million foreign born residents in Turkey with an additional 3 million refugees (Bel-Air, 2016). Combined, these two groups made up about $5.8 \%$ of the population in Turkey. The United States reached a record high 43.7 million foreign born residents in 2016 making up 13.5\% of the U.S. population according to a Pew Research report (López, Bialik, \& Radford, 2018). Most of these immigrants are documented $(76 \%)$ while the rest are unauthorized. Mexico has been the top country of origin, with most migrants coming for economic opportunity while some were fleeing violence. In addition, there have been increasing numbers of migrants from Asian countries, particularly China and India. Currently immigrants of Asian descent make up a higher overall portion of the immigrant community.

\section{Method}

In the United States, social studies is the most likely area of study for issues of migration to be addressed. Unfortunately, social studies is under threat in elementary classrooms as time devoted to math and literacy continues to limit time for other subjects (Fitchett \& Heafner, 2010). Furthermore, frequently when they do learn social studies it is through children's literatre and/or textbooks (Boyle-Baise et al., 2008). Due to the strictures of state baesd standardized testing in the United States, and the more centralized curriculum in Turkey, using both standards, and standards based textbooks to understand the impact of the social studies curriculum is a valid measure. While not representative of all states, Ohio, in the United States is a politically contested state, meaning it does not tend to be overly conservative or progressive in its state 
politics. In addition, it uses the expanding communities approach that many states in the United States use for their elementary social studies standards.

This research is a descriptive study. The document analysis technique was used for data collection. Document analysis uses the examination of written materials with information or facts intended to be investigated (Yıldırım \& Şimşek, 2013). Similarly, Patton (2014) stated that the written documents are one of the main methods of obtaining qualitative findings.

In this context, we examined and compared the way migration issues are written about in elementary school textbooks in Turkey and the United States. After preliminary investigations, we decided to use textbooks for grades one through three due to the absence of content related to migration in the grade four textbook in Turkey. Comparative analysis was used with Social Studies textbooks for grades one through three from the United States and Life Studies textbooks for grades one through three from Turkey. The data collected in the textbooks were collected through document analysis. In this context, the determination of the textbooks examined in the United States and Turkey a "criterion sampling" method was used. While criterion sampling was used to determine the subject and to determine the properties of the materials to be analyzed in relation to the subject, easily accessible sampling was used in obtaining the materials. Büyüköztürk et al., (2011) stated that criteria sampling and purposive sampleing are appropriate when researchers want to focus on a particular topic with certain qualifications.

\section{Data Collection and Data Analysis}

In this research, we discuss how issues of migration and immigrant are addressed in textbooks from both Turkey and the United States. The data set includes Social Studies textbooks from the state of Ohio in the United States for grades one through three (Berson, Howard, \& Salinas, 2007) and life studies textbooks from Turkey for the same grade band (Life Studies 1 Textbook (Demir, 2018), Life Studies 2 Textbook (Kuskaya, 2018) and the Life Studies 3 Textbook (Çelikbaş, Gurel, \& Ozcan, 2018).

The content was examined in terms of how migration issues are handled in the textbooks. In addition, when the information was given and students were asked to structure the subject, it was examined which points were emphasized more. Descriptive analysis was used to analyze the research data. We used descriptive analysis in which the data obtained were summarized and interpreted according to previously determined themes and in the context of cause-effect relations (Yıldırım \& Şimşek, 2013). Descriptive analysis technique was carried out in the framework of three activity steps; reduction of data, presentation of data, conclusion and verification (Türnüklü, 2000). Textbooks examined in this research; were examined by limiting data to the subject of migration, how the issue of migration is addressed the characteristics of the migrants presented in the textbook, which activity and evaluation processes were presented with the presentation of the examples and the similarities and differences between the textbooks were evaluated (The data obtained in the content analysis were evaluated by taking the opinions of two experts who completed their PhD in the field of Social Studies education in the US).

Determining which pages were related to migration was challenging, particularly with the textbooks from the United States. While there were pages that explitily addressed migration both in the past and the present using the word "immigrant" and directly discussing not only the challenges immigrants face but also the diversity they bring, there were other sections of the text that also talked about people com- ing from Europe to what is now known as the United States where the people were refered to as "settlers" or "colonists." These sections also discussed the challenges of coming to a new and unfamiliar land and highlighted the ways in which the Native Americans helped these immigrants adjust to life in North America. However, again, this group of people is refered to not as immigrants but as settlers or colonists. After the arrival of the settler immigrants is mentioned, Native Americans are never mentioned again. While this is an important factor to consider, for the purposes of this manuscript we are only considering time when migration and immigrants are expliticlty mentioned.

\section{Results and Recommendations}

Before looking at how immigrants and migration are included in the textbooks, we examined how the student competences, or standards, related to these issues are or are not present in the relevant curriculums of both countries. The subjects of migration and immigrants are included in the competence of students in Turkey at every grade level. In the US, migration and immigrants are addressed tangentially under the emphasis of recognizing cultural differences and individual characteristics and rights. Additional standards for Ohio that are less direct, but could include addressing challenges of migration and immigrants are included in italics. Shown below are issues of migration as found in grade-level competencies in Turkey and Ohio (United States) standards:

Life Studies Curriculum in Turkey (MEBa, 2018):

HB.1.5.4. Realize living in our country together with people from different cultures.

The subject, is explained by the people who have migrated from their countries compulsorily or voluntarily.

HB. 2.5.7. It respects the life styles and habits of people in different cultures living in our country.

The subject is explained by the people who have migrated from their countries compulsorily or voluntarily.

HB. 3.5.7. Participates in social responsibility projects for the problems of people in different cultures living in our country.

Social Studies Standarts 1-3 (Ohio's learning standards: Social Studies: OLSSS, 2018):

Grade One:

6. Families interact with the physical evironment differently in different times and places.

7. Diverse cultural practices address basic human needs in various ways and may change over time.

8. Individuals have responsibility to take action toward the achievemet of common goals in homes, schools and communities and are accountable for those actions.

9. Collaboration requires group members to respect the rights and opinions of others.

Grade Two:

6. The work that people do is impacted by the distinctive human and physical characteristscs in the place where they live. 
8. Cultures develop in unique ways, in part through the influence of the physical environment.

9. Interactions among cultures lead to sharing ways of life.

Grade Three:

8. Communities may include diverse cultural groups.

When these competencies/standards are considered, it is understood that the emphasis on coexistence and cultural richness is aimed at attracting the attention of the students to the concepts of migration and immigrants.

In this section, we present the content around migration issues in Turkey and US textbooks according to grade levels. Below are the rates at which issues of migration are discussed in the textbooks in Turkey and US.

Table 1. Migration and Immigrant in Turkey and US Textbooks

\begin{tabular}{|c|c|c|c|}
\hline Textbooks & Title & $\begin{array}{l}\text { Total } \\
\text { number } \\
\text { of pages }\end{array}$ & $\begin{array}{l}\text { In } \% \\
\text { of all } \\
\text { textbook } \\
\text { pages }\end{array}$ \\
\hline Life Studies 1 & Living Together & 2 & 1 \\
\hline Life Studies 2 & $\begin{array}{l}\text { Different Cultures, } \\
\text { Different People }\end{array}$ & 3 & 1.2 \\
\hline Life Studies 3 & $\begin{array}{l}\text { New Country, New } \\
\text { Friends }\end{array}$ & 2 & 1 \\
\hline $\begin{array}{l}\text { Social Studies, } \\
\text { A Child' View }\end{array}$ & $\begin{array}{l}\text { People Find New } \\
\text { Homes, Expressing } \\
\text { Culture, Sharing } \\
\text { Celebrations }\end{array}$ & 23 & 7.5 \\
\hline $\begin{array}{l}\text { Social Studies, } \\
\text { People We } \\
\text { Know }\end{array}$ & $\begin{array}{l}\text { Many People, One } \\
\text { Country, } \\
\text { Celebrating Culture }\end{array}$ & 16 & 5 \\
\hline $\begin{array}{l}\text { Social Studies, } \\
\text { Our } \\
\text { Communities }\end{array}$ & $\begin{array}{l}\text { Moving to New } \\
\text { Places, Sharing } \\
\text { Cultures }\end{array}$ & 15 & 3.4 \\
\hline
\end{tabular}

When the table is analyzed, 3.4-7.5\% of the Turkish textbooks discuss migration and $1-1.2 \%$ of the US textbook addresses these issues. This would indicate that Turkey devotes a higher percentage of its textbook content to issues of migration than the United States.

\section{Migration and Immigrants in First Grade Textbooks}

In the Life Studies 1 textbook, the issue of migration and immigrants is explained under the title "Living Together".

With the subject of Living Together, it was intented to tell first year students that people from different nationalities live together and explore the subject of migration at the same time. Through the speech balloons, students were asked to introduce themselves and explain why they came to Turkey. Three students from Germany, Afghanistan and Syria have described their experiences as immigrants in Turkey. Especially making emphasis to migration in the speech bubble, is now made particularly emphasized that Turkey is their homeland. This situation is seen as an effort to accept the new countries that immigrants have to live in and to accelerate the process of getting used to easier. Another noteworthy transmission was the students' speaking of Turkish, recognizing the geographic locations of the country and their relations with the people of the country. At the beginning of the subject, there is a directive in the form of the preparation question to share the knowledge of whether there are migrants in their immediate vicinity or where they live. In the second page of the student activity, the definition of migration is included and performance tasks are given to help the immigrants and reveal the importance of living together. In the Life Studies grade 1 textbook, It was noted that there is an attempt to give information about migration and to help them communicate with migrants and to integrate with their community.
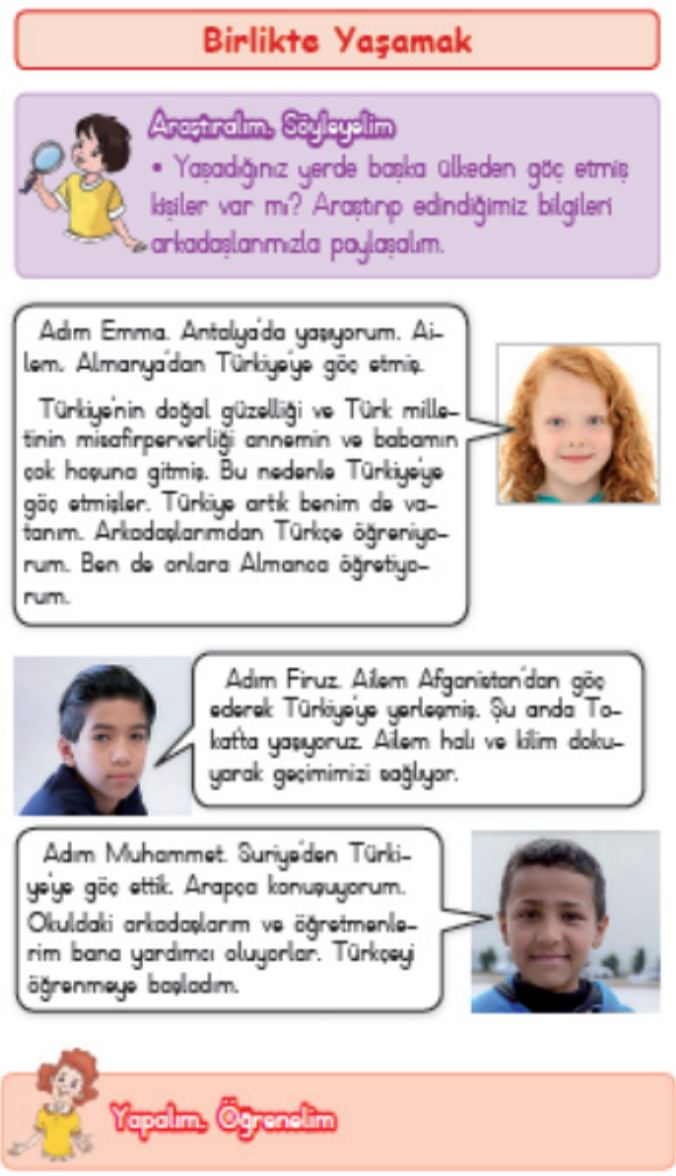

Birtikte Yogamak

hoanlar çalsamak doha iy yopamak sovas gbi nedenlerle basha allelere goc edebitiler. Ûllemize de bu nedenle goc etmis insarlar vardr.

Üllkemize goc̣ etmiẹ olan bu insanlara yordma olmak ic̣in neler yapabiliriz? Yazorak anlatdim.
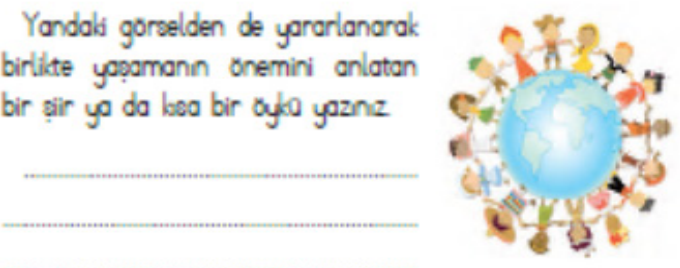

Figure 1. Subject of migration and immigrants in Life Studies Grade 1 textbooks in Turkey 


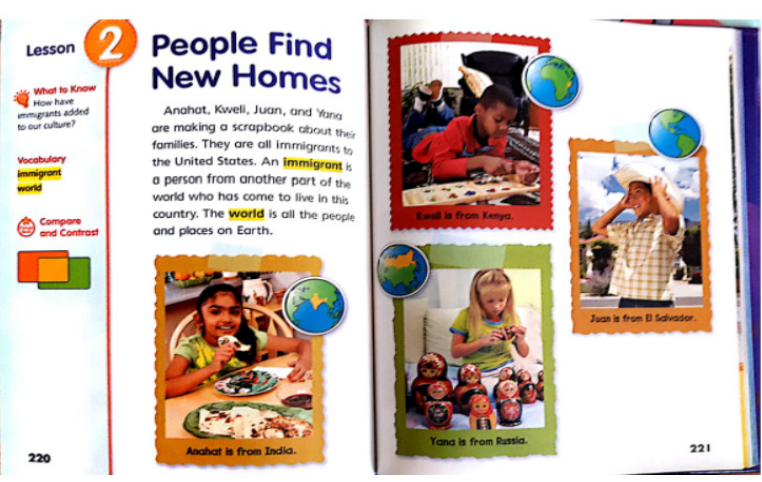

Figure 2. Subject of migration and immigrants in Social Studies Grade 1 textbooks in US-a

Migration and immigrant subjects in the US $1^{\text {st }}$ Grade Social Studies textbook are described in People Find New Homes. The lives of four immigrants from India, El Salvador, Russia and Kenya were described in American society. The definition of the immigrant and the question of preparation have been started with the aim of discussing what the immigrants contribute culturally to society.

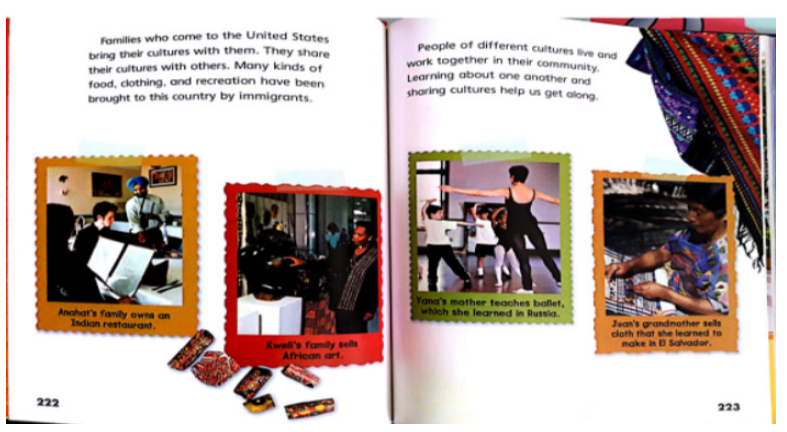

Figure 3. Subject of migration and immigrants in Social Studies Grade 1 textbooks in US-b

Examples of migrant families' lives in the community and their work in the US are given. At the same time, the sample families selected from four different countries continue their culture and also gain some of their achievements in their homeland; it is seen that the emphasis is on traditional art and education.

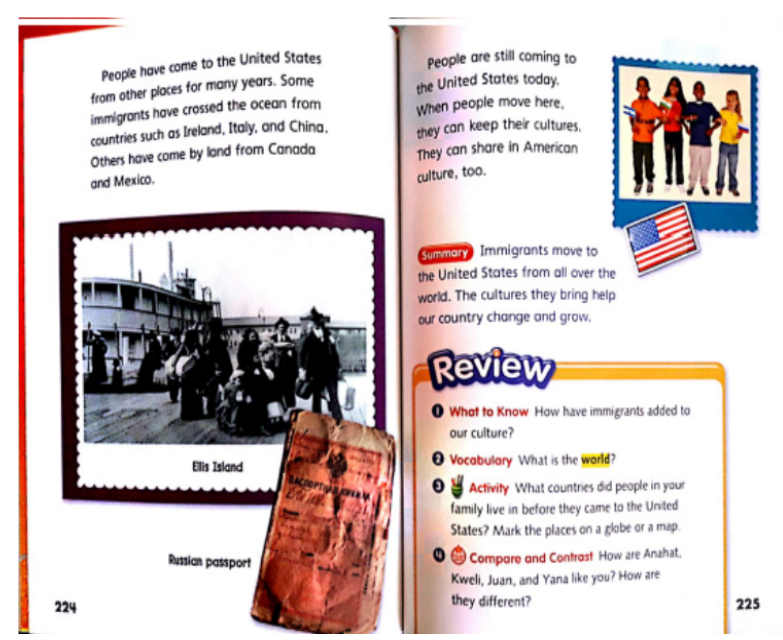

Figure 4. Subject of migration and immigrants in Social Studies Grade 1 textbooks in US-c

In the continuation of the issue, it was emphasized that immigrants came to the US from other countries, many years ago, some immigrants came from overseas countries and even today some migrants arrived. The fact that immigrants came to the US created a cultural richness and underlined that the migrants were protecting their own culture. At the end of the subject, it was asked that migrants carry cultures from different regions of the world to the US and that this was a cultural wealth, and also their students would be an immigrant and to investigate where they came from. In this continuation (p. 226-230) cultural differences are mentioned and it is explained that the US is a rich immigrant country and it continues with the transfer of people from different cultures as migrants in the US. In the US Social Studies 1 textbook, it is seen that the information about migration and immigrant is explained in terms of the subject matter of migration and immigrants. The more emphasis on migrants is that they have a culture of their own and that this is a cultural wealth for the US. At the same time, it is emphasized that there is a historical process of migration and that it continues after the case studies.

\section{Migration and Immigrants in Second Grade Textbooks}

In the Life Studies 2 textbook, the issue of migration and immigrants is explained under the title "Different Cultures, Different People"

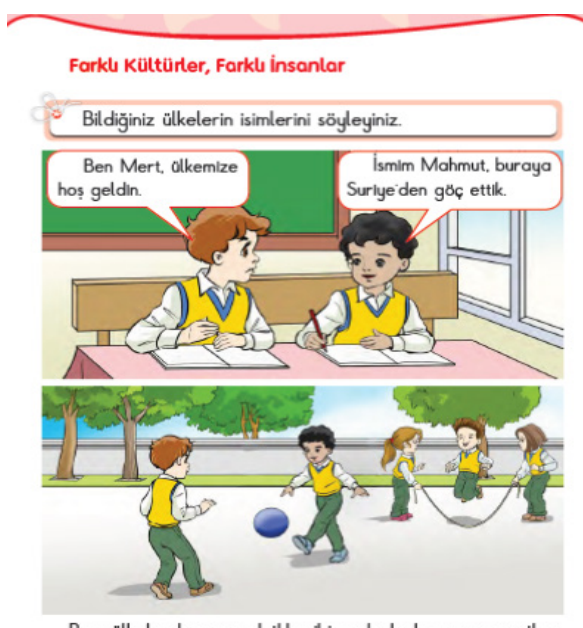

Bazı ülkelerde savaș. kuttuk gibi nedenlerle yașam șartları zorlașmaktadir. Bu tür ülkelerin vatandașları daha ịi șart-

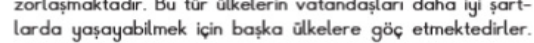

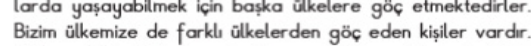
Onlara. ülkemizde karșlaștkları zorlukları gidermeleri için yardim etmeliyiz.
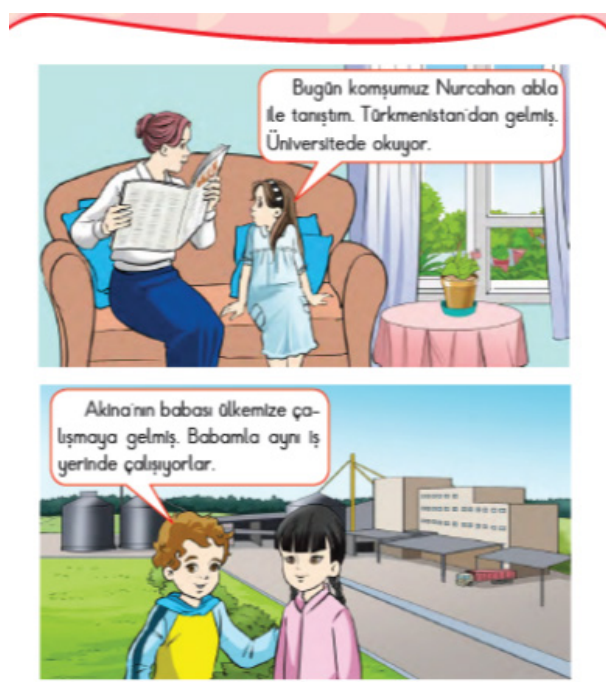

Çeșitli nedenlerle bașka ưlkelerden ưlkemize gọ̈ç eden kișilere karṣ anlayșl olmalyzz Onlarin yașam tarzlanna ve alșkanliklarna sayg duymalyzz.

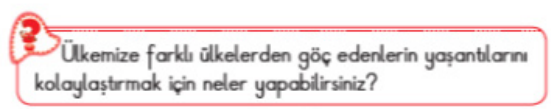

Figure 5. Subject of migration and immigrants in Life Studies Grade 2 textbooks in Turkey-a 
In the second grade textbook, it is seen that the migration and immigrant concepts are pointed out by giving speech to the children of different migrants as in the first grade. It is seen that two students of the same grade are included in the topic. The first student "Mert" is Turkish and his classmate "Mahmut" is Syrian. When Mert said welcome to Mahmut, Mahmut said that he migrated from Syria. Subjects continued on, because the causes of migration and migrants from different countries in Turkey and mentions the necessity to help them. On the other page where a student's neighbors emigrated from Turkmenistan to Turkey for educational purposes while other students are seen as giving place to talk with a Japanese friend living in Turkey due to his father's job.

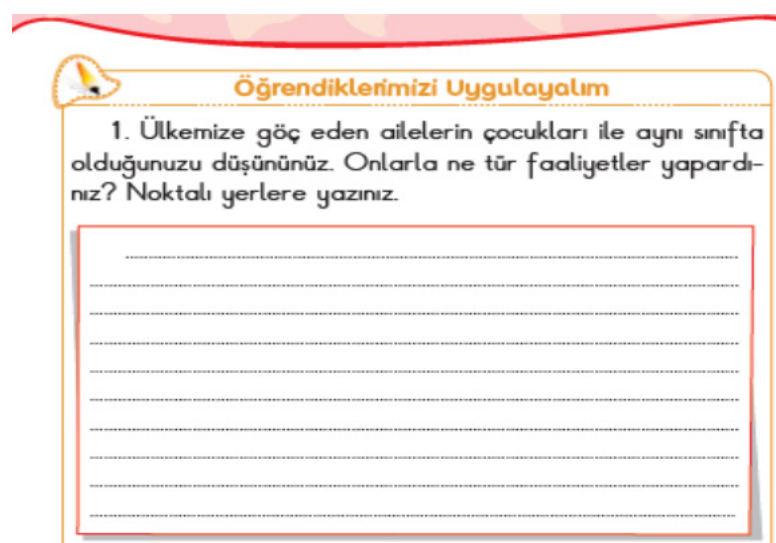

2. Așağıdaki form. kendinizi değerlendirmeniz amaçyla düzenlenmiștir. Size uygun olan seçeneği ${ }^{~} \checkmark$ ile ișaretleyiniz

\begin{tabular}{|l|l|l|}
\hline \multicolumn{1}{|c|}{ ÖLC̣ÜTLER } & Evet & Hayır \\
\hline $\begin{array}{l}\text { Farklı ülkelerden gelen çocuklarla oyun } \\
\text { oynarım. }\end{array}$ & & \\
\hline $\begin{array}{l}\text { Farklı ülkelerden gelen kișilerin alıșkan- } \\
\text { lıklarına saygı duyarım. }\end{array}$ & \\
\hline $\begin{array}{l}\text { "Hayır" ișaretlediğiniz davranıșlar için kendinizi geliștir- } \\
\text { melisiniz. }\end{array}$
\end{tabular}

Figure 6. Subject of migration and immigrants in Life Studies Grade 2 textbooks in Turkey-b

In the end-of-term evaluation section, we see that two different performance tasks are given to the students. First, they are asked to imagine that they are immigrant students in their classrooms and to plan how they can do joint activities with other students. The second task is to complete the attitude scale towards immigrants with two items.

In this attitude scale, there are two items: immigrants, playing with students and respecting their habits. Students who have negative answers are asked to improve themselves positively by questioning these behaviors.

When we look at the subject matter of migration and migrants in the Life Studies 2 grade textbook, it is evident that the idea of migration and its types and communication with migrants and helping them to facilitate their integration with society are tried to be given as in the first grade. It is seen that this class level focuses on the idea of coexistence with migrants and the idea of living together in society, rather than the explanations given at the knowledge level.

"Many People, One Country "subject of migration and migrants was addressed in US $2^{\text {nd }}$ Grade Social Studies textbook. The subject was introduced to the students with an example that can be seen frequently in American society. Restaurants from different cultures on a Street; You can see the French, Italian and Chinese restaurants and the issue is raised by saying that you can see that people speak Arabic, Spanish and other languages. The reasons for the migration of an immigrant; malnutrition, war escape etc. are explained with examples. At the same time, the book explained that America is a country that has been receiving immigrants for many years. In the visuals used, it is emphasized that the immigrants are compatible with US citizens and it tries to show that the immigrants have been coming to America for a long time.

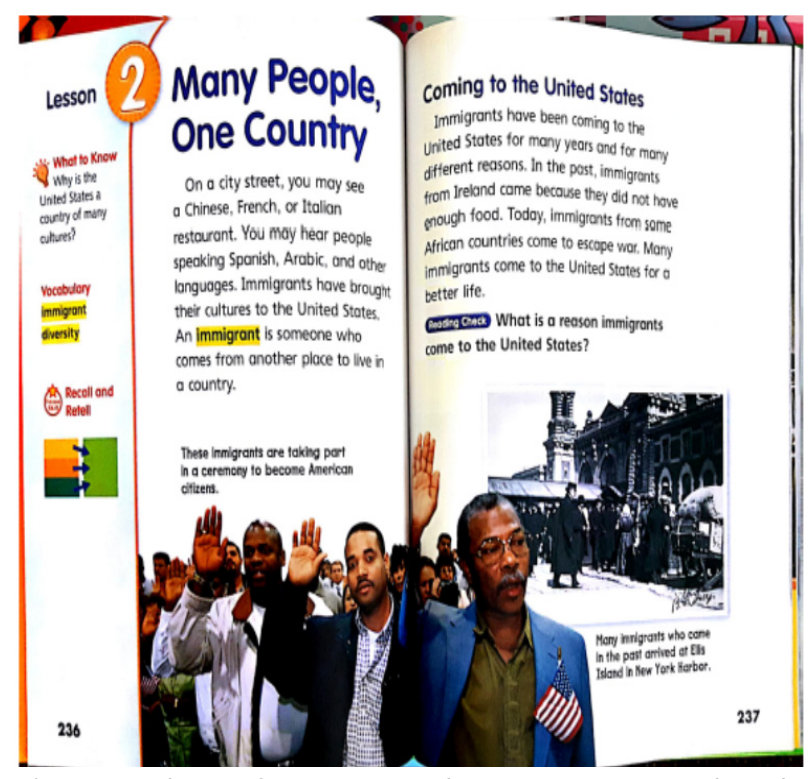

Figure 7. Subject of migration and immigrants in Social Studies Grade 2 textbooks in US-a

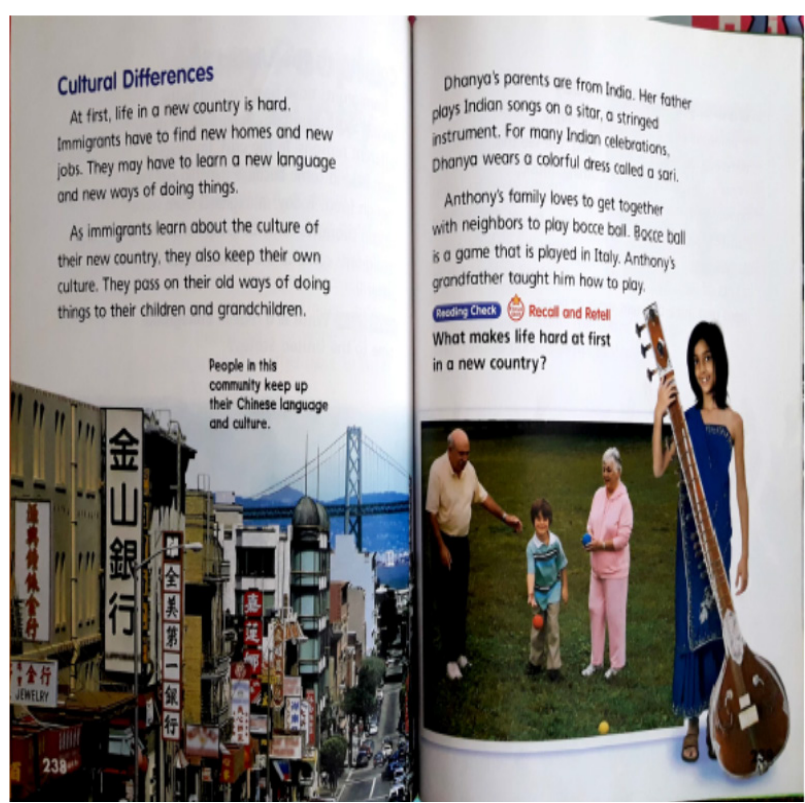

Figure 8. Subject of migration and immigrants in Social Studies Grade 2 textbooks in US-b

In the continuation of the issue, it is seen that the difficulties faced by immigrants coming to a new country were emphasized. New home, new job, learning a new language and many new things are emphasized that are difficult for immigrants. At the same time, it is explained that immigrants adapt to the new culture without forgetting their own culture and this takes a long time. It was also seen that different examples from Italy and India were emphasized in the US society in terms of living their own culture and being together.

It was emphasized that the immigrants in the US created a cultural diversity with their food, music, clothes, language and beliefs and thus opened the way for learning different ideas. 
In the US, people are said to be Americans and everyone is equal and free, even if they are from different cultures.

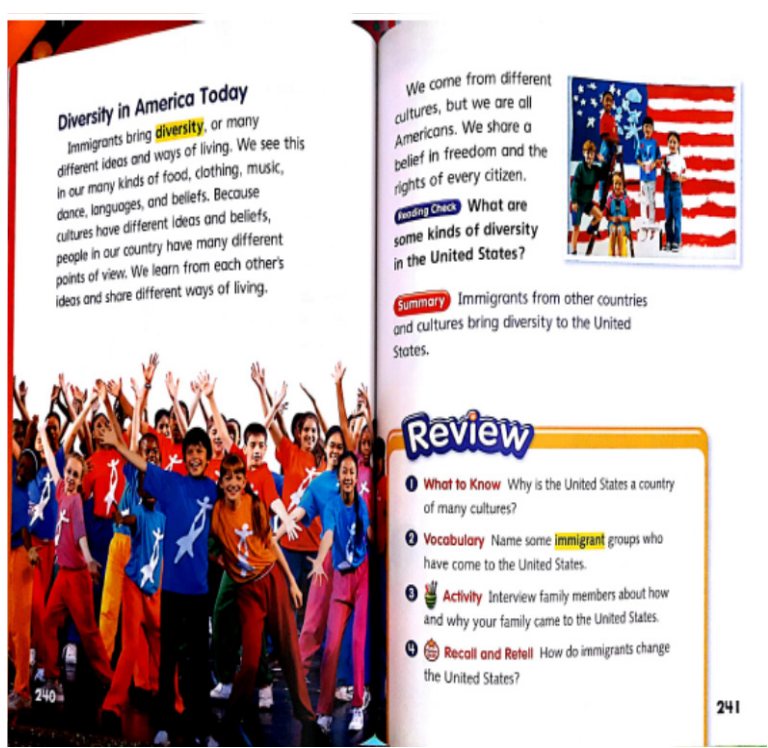

Figure 9. Subject of migration and immigrants in Social Studies Grade 2 textbooks in US-c

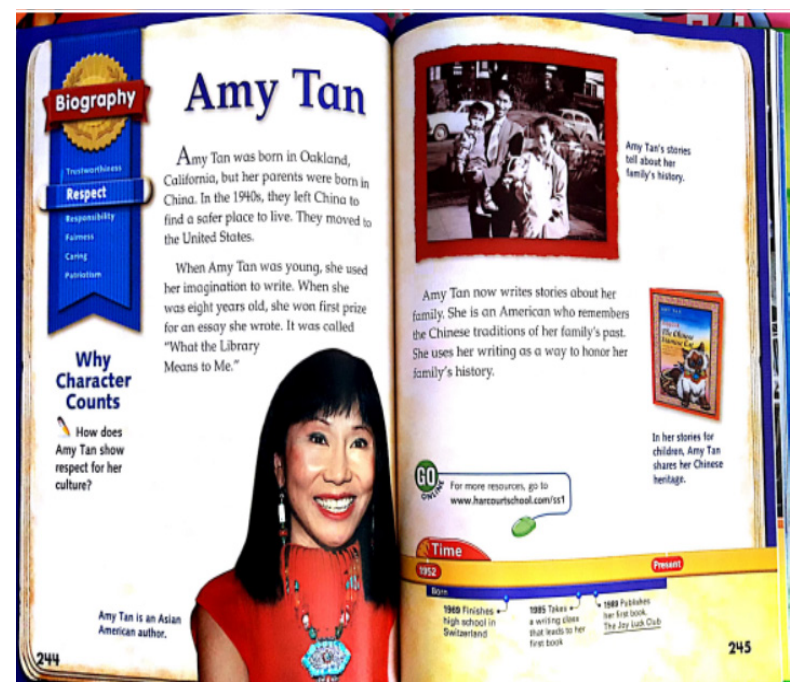

Figure 10. Subject of migration and immigrants in Social Studies Grade 2 textbooks in US-d

The US Social Studies 2 textbook continued with sample success stories and biographies of migrants, and special day celebrations of different cultures were included. As in the example above, the story of Amy Tan, a Chinese immigrant, has been told about her success story as an immigrant at a very young age. It was also emphasized that immigrants are equal in society and at the same time they are not different because the come from other country.

In the US Social Studies 2 textbook, it appears that the meaning of the concepts of migration and immigrant and the difficulties experienced by immigrants are considered when the subject matter of migration and immigrants is examined. More emphasis is put upon how migrants can achieve significant success as a US citizen and can continue their culture comfortably. It is seen that the real visual materials and sample stories and the idea of living together in harmony with the society are especially emphasized. It is noteworthy that cultural differences are an important variety and richness for the US and that every citizen has equal rights.
Migration and Immigrants in Third Grade Textbooks

In the Life Studies 3 textbook, the issue of migration and immigrants is explained under the title "New Country, New Friends".
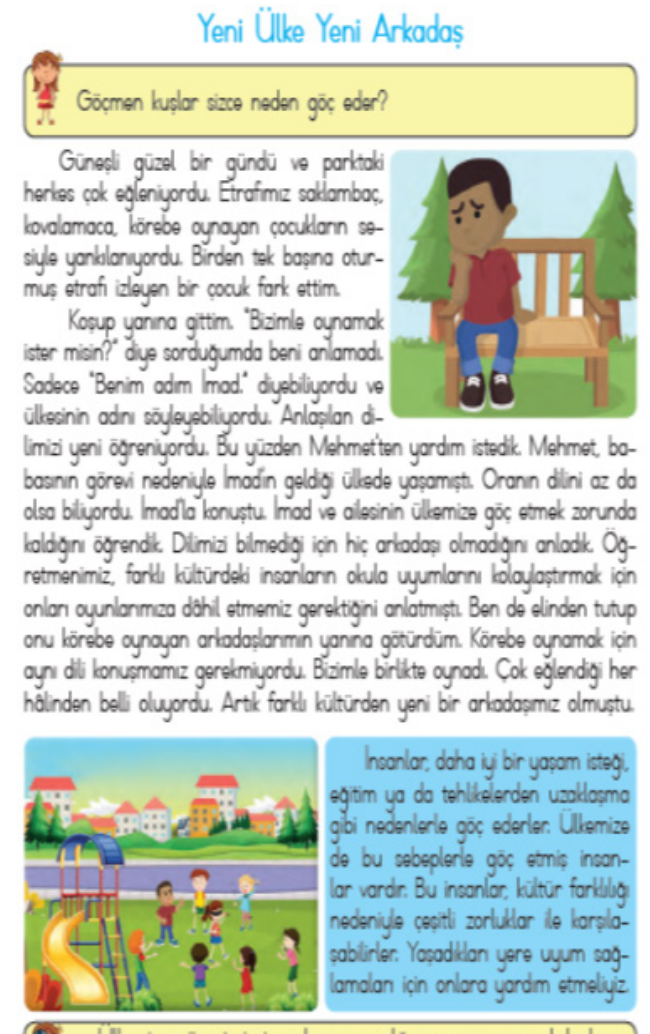

hoonlar, doho iy bir yosam istog. agtim yo do tohlikelerden usollosmo gibi nedenlerle göc ederler. Ullemize de bu sebeoplerle gö stimia insonlor vardr. Bu insonlor, kütur forldigg

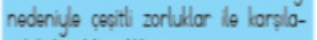
sobiliner. Yosodillan yere uyum soglamolan icin onloro yordm stmeliyz

Uilemize göc stmig insorlarn yosodg yere uyumunu bolaylostrmok icin neler yopldgni aroținnt?

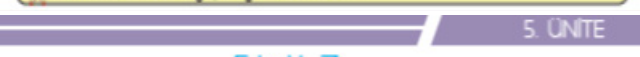

Etkinlik Zaman!

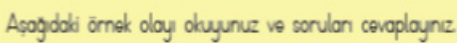

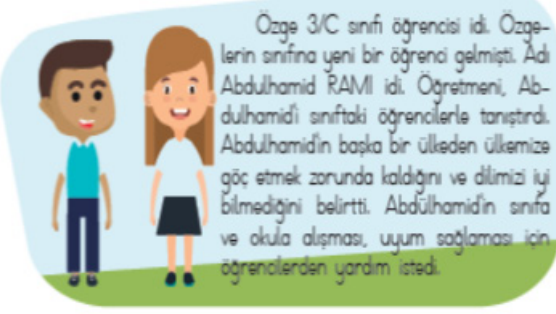

Sacee Ozge ve arladaslon. Abdühamidin snfo ve okula uum soglamas ipin neler yapabilirler? Onerileriniza aşagya yazne

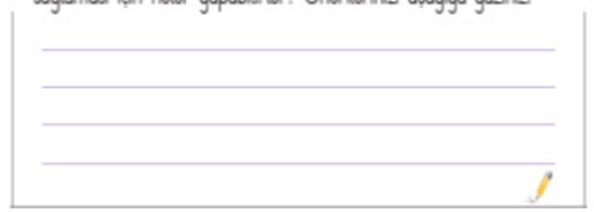

Sz boska bir ülleye göc etmek zorunda kolsaydnz neler hissederdiniz? Duggu ve düsünceleriniz aşogya younz

Figure 11. Subject of migration and immigrants in Life Studies Grade 3 textbooks in Turkey 
In the third grade textbook, it is seen that the content of the subject of migration and immigrants are addressed through a story. A child standing alone in the park does not know the language and did not participate in the games, but later an immigrant child with a little knowledge of the language helps the other child to play with the group. As a result of bringing together children from different cultures, cooperation has been shown to be a natural result. Again, on the activity page, an immigrant student who did not speak a language was asked to say what could be done to adapt to the school. Finally, the students were asked to think about what they would feel if they were an immigrant.

When we look at the content of migration and immigrant subjects in the Life Science Grade 3 textbook the reasons for migration are explained and the situation of immigrants in society is explored as in the first two grades. At the same time, they tried to explain what they felt through empathy. It is evident that migration and immigrant subjects are handled in Life Science textbooks in a similar way in the first three grades, and that there is a difference in the level of knowledge and understanding of migration and migrants. The problems experienced by the immigrants, the processes of integration with the society, cultural differences and their harmony in a new country, their identity and being a member of a new country and how it is difficult to get together are not explained. In the visual materials used, it is evident that a scenario based on the appropriate drawing was made and real visual elements were not used. It was also observed that the performance tasks given in the end-of-term evaluations were very important for adopting the idea of empathy and coexistence in society.

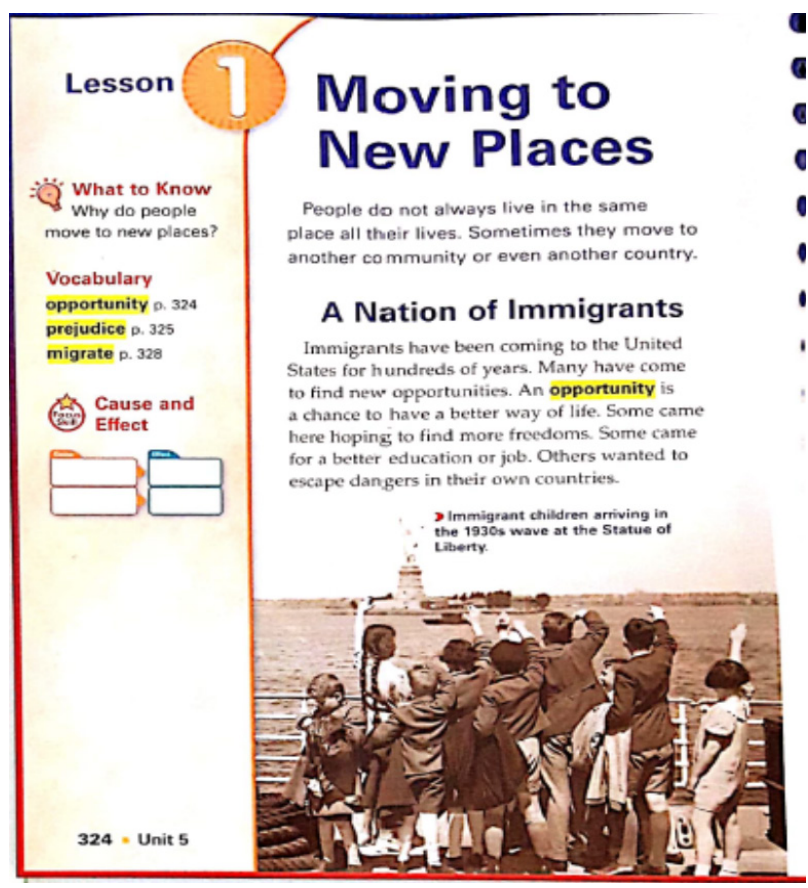

Figure 12. Subject of migration and immigrants in Social Studies Grade 3 textbooks in US-a

Migration and migration issues in the US and $3^{\text {rd }}$ Grade Social Studies textbook; were explained with "Moving to New Places and Sharing Culture" topics. Moving to New Places has explained the reasons for migrants to migrate to the US. It explained that they migrated to the US for a better life, education and employment opportunities. Migration from the other continents of all continents is given by the migration map. In the third grade textbook, the difficulties faced by the immigrants is described in more detail than in the other two classes that were included. It is stated that migrants live a more difficult life in terms of housing, making money and feeding.

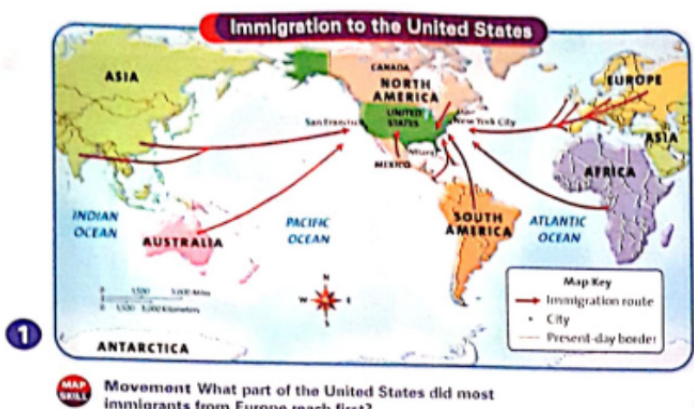

Movomeant What part of the United States did most
immingrants trom Europe reach first?

Immigrants Face New Problems In the past, immigrants to the United States faced many problems. They often had to live in crowded apartments in the older parts of big cities. They had little money for food.

(2)

Sume immigrants also faced prejudice (IRETI-jul1-duhs). Prejudice is the unfair feeling of thate or distike for people of a certain group, race, or neligion. Immigrants were often pwis less money than other workers for the same job. They ato lad

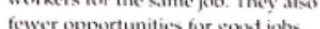
Gersing chece Oे Cause and Effect Why hove immigrants come to the United

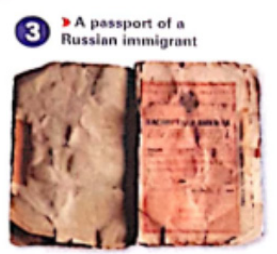

Chapter $9=325$

Figure 13. Subject of migration and immigrants in Social Studies Grade 3 textbooks in US-b

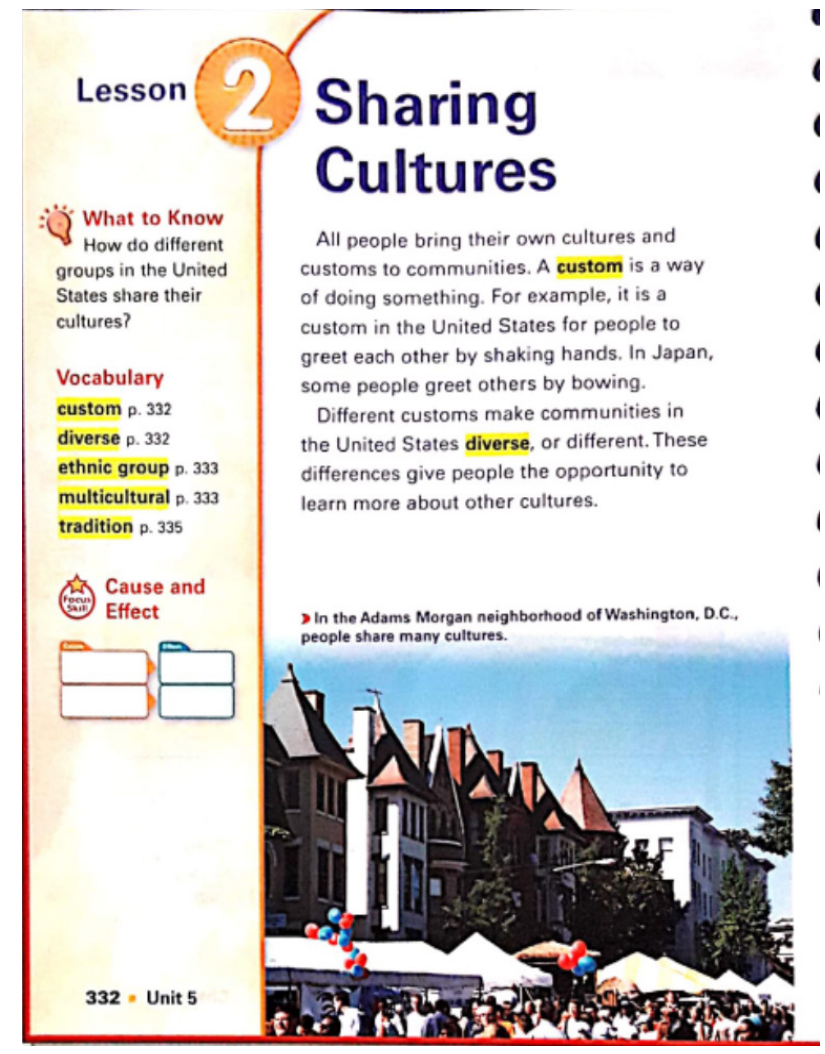

Figure 14. Subject of migration and immigrants in Social Studies Grade 3 textbooks in US-c

Another subject related to migrants in the third class textbook is the "Sharing Cultures" topic. It is explained that people from different cultures form cultural diversity and wealth, and that multicultural neighbor relations prevail in cities. Again, a grocery photo from a small city from Georgia was shared; Although this city is very small, it is emphasized that it has a great ethnic diversity. 


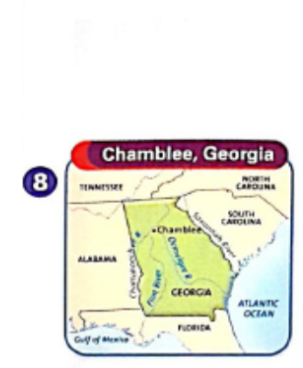

(9) Chamblee, Georgia

Chamblee (SHAM•blce) is a small city in Chamblee (SHAM-blce) is a small city in Georgia. Abrout 10,000 people live there Like Cleveland, Chamblee has diftert ethnic neighborhoods. Its largest ethnic groups include Hispanic and Southeast Asian immigrants.

An International City Visitors to Chamblec have many opportunities to enjoy the city's cultural diversity. It has about 100 different businesses owned by immigrants. Many of businesses owned by immigrants. Many of these are restaurants that offer traditio foods from other countries. There are Mexican, Vietnamese, Greek, Thai, and other restaurants. There are also Chine bookstores and a Mexican music store

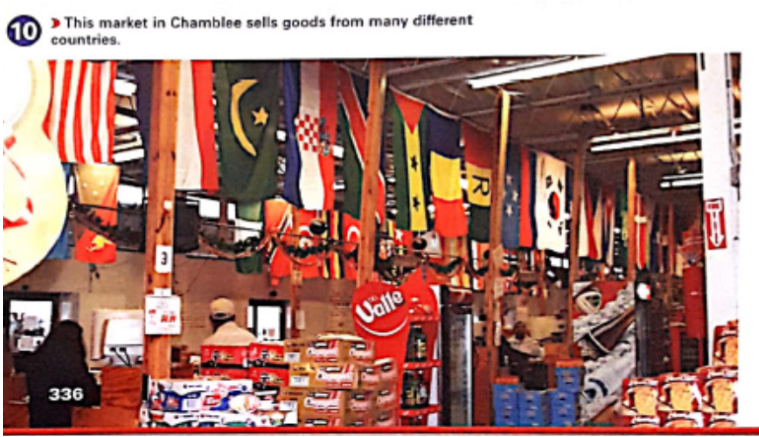

Figure 15. Subject of migration and immigrants in Social Studies Grade 3 textbooks in US-d

\section{Discussion, Conclusion And Suggestions}

In this research, it is discussed how migration and immigrant issues were examined in a comparative way in textbooks in Turkey and the United States. For this purpose, Life Studies and Social Studies textbooks of both countries were examined in terms of how migration and migrants were handled comparatively in these books. In the Life Studies and Social Studies courses, which aim to develop effective citizenship in society, to culture and aim to become an individual member of the society, adopted as migration societies USA's, and Turkey's which especially in the last five years, accepts only about 3.6 million immigrants (Göç Idaresi, 2019) from Syria, at elementary level, it is extremely important to reveal how discusses issues of migration and immigrants.

Turkey and the US curriculum, the issue of migration and immigrants, has in the competencies related to cultural differences. In the Turkey's curriculums which is more central than USA, there are explanations about the migration and immigrants and said that this orientation takes place on the subject of direct routing of content to cover relevant issues in light of textbooks. In the US social studies curriculum, the issue of cultural differences was more open-ended, where textbook users were given the opportunity to further link and elaborate on the issue. In Turkey, a Life Studies curriculum (MEBa, 2018) of migration and immigrant issues at every grade level have been found especially highlighted. In the US social studies curriculum (Ohio Department of Education, 2017)., there is no explanation for direct migration and immigrants. Cultural differences and coexistence were observed as two different competences at each grade level.

While there are many studies on migration and migrants, it can be said that there are limited studies investigating how migrants are handled in textbooks (Hintermann, 2009; Soysal, 2005). A study by Hintermann (2009) on Migration and Memory in Austria, and a Reluctant Migration Country in Austria reveals how migration and migration are handled, especially in history (Social Studies textbooks are included) and geography textbooks. In 8 books examined in this study, migration and migrants were included between $0.6 \%$ and $4.9 \%$ in the total of books. It is determined that the subject is given in the headings "New problem: language of migrants, Migration today, Problems of migration, The richest and the poorest countries in the World, Change of society etc." In this research the migration and immigrant issues in Turkey and US textbooks "Live Together, Different Cultures, Different People, New Country New Friends, Many People, One Country, People Finder New Homes" are given under subject headings. The total manual migration and migration issues in Turkey $1 \%$ to $1.29 \%$ 'is also covered by the US it is seen that incorporation of the total book $3.4 \%$ to 7.5\%. According to Hintermann (2009) the subject of immigrants in textbooks; focuses on the adaptation processes of migrants, working conditions and problems. This similar to the contents in the Life Studies textbooks in Turkey. In the US, however, it can be said that the content of the subject in terms of immigrants focuses on the cultural richness and the preservation and preservation of their culture by covering migrant problems and historical processes.

Life Studies Grade 1 textbooks (Demir, 2018) in Turkey, has only one topic under the concept of migration and immigrant. The content of the subject was determined by the knowledge of migration and immigrants, and the idea of communicating with the Immigrants and helping them to facilitate their integration with society. The information contained in the textbook focuses on assisting immigrants in the process of adaptation to society, particularly in studies related to migration and migrants. In the literature, it is seen that the biggest problem experienced by migrants is their living conditions and adaptation problems. Based on both living conditions and adaptation problems, it is stated that family communication and school life of children are affected (Chuang \& Gielen, 2009; Browne et al, 2017; Davies \& McKelvey, 1998; Stodolska, 2008). In the US Social Studies Grade 1 textbook (Berson, Howard, \& Salinas, 2007), when we look at the subject matter related to immigrants and immigrants, it is seen that first of all, migration and immigrant are given. It can be said that the textbook tries to make students comprehend these ideas from a young age, considering the willingness of host countries to help migrants and to be seen as part of society. More emphasis on migrants is the idea that they have a culture of their own and that they maintain it, and that this is a cultural wealth for the US. At the same time, a historical process of migration has been emphasized and the emphasis is evident in the case studies used in the texts. The information contained in the textbooks shows that in many studies (Bhugra \& Becker, 2005; Ojeda, Flores, Rosales, \& Morales, 2011; Bhugra, 2004), migrants' desire to protect their cultural identities and its support is important for facilitating the process of adaptation to the communities in which they live.

Migration and immigrant issues, in the Life Studies Grade 2 textbooks (Kușkaya, 2018) in Turkey, has been seen only in one subject. When the content of the subject is examined, it is seen that the idea of migrants and their communication with the immigrants and the idea of helping them to facilitate their integration with the community is just same as in the first grade. In this grade, rather than the explanations given at the level of knowledge, it is observed that the focus is on the idea of living together and facilitating the adaptation process of migrants with performance tasks. The idea of living together in this textbook and student study activity and seeing migrants as part of the society is extremely important. However, the fact that it is only under one topic shows that this issue is given limited attention.

In the US Social Studies 2 textbook (Berson, Howard, \& Salinas, 2007), when we look at the subject matter related to immigrants and migrants, we see that they use rich information content and examples, more so than the first grade textbook. In the same way, it is possible to say that the US Social Studies 2 textbook is given a richer transfer process 
according to the content of the Life Studies 2 textbook. The Social Studies Grade 2 textbook shows an emphasis on the meaning of the concepts of migration and immigrant and the difficulties experienced by immigrants. A more recent emphasis on migrants is that they can achieve considerable success as a US citizen and can continue their culture comfortably. It is seen that the real visual materials and sample stories and the idea of living together in harmony with society are especially emphasized. It is noteworthy that cultural differences are an important element in the US textbooks and that every citizen has equal rights. Most research on migrants state is that they are faced with many new situations in society, and these are seen as major challenges in the lives of migrants (Hall \& Cuellar, 2016; IOM, 2013; Landale, Thomas, \& Van Hook, 2011; Zimmerman, Kiss, \& Hossain, 2011;). The Social Studies Grade 2 textbook draws attention to these challenges. At the same time, adapting to the society in a healthier way, bringing its cultural awareness to life together with the process of harmonization with the new culture provides a healthy adaptation process for migrants (Bhugra, 2004; Bhugra \& Becker, 2005; Kaushik, \& Drolet, 2018). In the textbook, these issues are addressed with real visual elements and life stories. When we look at the subject matter of migration and immigrants in the Life Studies Grade 3 textbook; As in the first two grades, migration and the causes of migration and the situation of immigrants in society are given. At the same time, the empathy of the migrants was established and their feelings were tried to be explained. In the course book, in particular through empathy with performance tasks and recognizing the problems of immigrants, The issue of assisting them, the concern of immigrants being admitted to the new society, will help the migrants to overcome their psychological problems more easily (Alegría, Álvarez, \& Di Marzio, 2017; Kirmayer et al., 2011; Mood, Jonsson \& Låftman, 2016). And it will further strengthen the idea of coexistence among future generations of society. In the US Social Studies 3 textbook, migration and migrants have been described in relation to the issue of cultural diversity as in other books. In this book, unlike the other two classes, more attention was paid to the problems experienced by migrants. In addition, some statistics on migration movements and immigrants from different continents are included in the USA. In addition, it continued to be emphasized, as in the other two books, that immigrants living in American cities moved their culture to their new countries and that this was a source of wealth for the US.

Another important point in the textbooks of both countries is the visual materials used in books. In Turkey, more pictures (drawings made based on the scenario) were used, the US textbooks used more real visual evidence such as photographs. If the real visual elements used in textbooks are thought to affect the learning process more favourably, more real visual materials are recommended to benefit in Turkey textbooks. As a result of this study, there are many studies on migration and migrants in the literature, but there is limited research on the subject of immigrants in the textbooks. A historical process can be screened in the textbooks about immigrants. In the historical process, it can be investigated how the migration and migratory expression has changed. Again with regard to immigrants, first-middle and high school textbooks, especially in social studies, history and geography courses; research can be carried out on how to present a topic content. Also in the research, integration processes of immigrants in Turkey is evident mostly at elementary level, and there is a particularly emphasis on communication with migrant issues. While preparing the course book, immigrant rights related to immigrants and migrants, successful migrant stories and their importance for both their own countries and the society they live in could be expressed. The opportunities provided by the migrant country can be explained from the perspective of the migrants. Assuming that migration is an international issue, examples of experiences of migrants and migrants of each country in a globalized world can be explained briefly

\section{References}

Akıncı, B., Nergiz A., \& Gedik, E., (2015), Uyum süreci üzerine bir değerlendirme: Göç ve toplumsal kabul. Göç Araştırmaları Dergisi, 1(2), 58-83.

Aksoy, Z. (2012). "Uluslar arası göç ve kültürlerarası iletişim", Ulus/ararası Sosyal Araştırmalar Dergisi, 5(20), 292-303.

Alegría, M., Álvarez, K., \& Di Marzio, K. (2017). Immigration and Mental Health. Current Epidemiology Reports, 4(2), 145155

Bardsley, D. K. \& Hugo, G. J., (2010). Migration and climate change: examining thresholds of change to guide effective adaptation decision-making. Population and Environment, 32, 238-262.

Bel-Air, F. D., (2016). Migration profile: Turkey. Policy Brief. Issue 2016/09 December, 2016 European University Institute Migration Policy Center. Retrieved from: http://cadmus.eui.eu/bitstream/handle/1814/45145/ MPC_PB_2016_09.pdf

Berson, M. J., Howard, T. C. \& Salinas, C. (2007). Social studies, a child'view (OHIO), Harcourt School Publishers, Florida.

Berson, M. J., Howard, T. C. \& Salinas, C. (2007). Social studies, people we know, (Berson, Howard \& Salinas, 2007) (OHIO), Harcourt School Publishers, Florida.

Berson, M. J., Howard, T. C. \& Salinas, C. (2007). Social studies, our communities, (Berson, Howard \& Salinas, 2007) (OHIO), Harcourt School Publishers, Florida.

Browne, D. T., Kumar, A., Puente-Duran, S., Georgiades, K., Leckie, G., Jenkins, J. (2017). Emotional problems among recent immigrants and parenting status: Findings from a national longitudinal study of immigrants in Canada. PLOS ONE 12(4):e0175023. https://doi. org/10.1371/ journal.pone.0175023

Bhugra, D. (2004). Migration, distress and cultural identity. British Medical Bulletin, 69, 1-13.

Bhugra, D. \& Becker, M. A. (2005). Migration, cultural bereavement and cultural identity. World Psychiatry (WPA), 4(1), 18-24.

Boyle-Baise, M., Hsu, M., Johnnson, S., Serriere, S. C., \& Stewart, D. (2008). Putting reading first: Teaching social studies in elementary classrooms. Theory and Research in Social Education, 36(3), 233-255. doi: 10.1080/00933104.2008.10473374

Büyüköztürk, Ş., Çakmak, E. K., Akgün Ö. E., Karadeniz, Ş., \& Demirel F. (2011). Bilimsel araştırma yöntemleri. Ankara: Pegem.

Castles, S. \& Miller, M. J. (2008), Göçler çă̆ı modern dünyada uluslararası göç hareketleri, (Çev. B. U. Bal, İ. Akbulut), İstanbul: Bilgi Üniversitesi Yayınları, 257.

Chuang, S. S. \& Gielen, U. P. (2009). Understanding immigrant families from around the world: Introduction to the special issue. Journal of Family Psychology, 23(3), 275278.

Çelikbaş, E., Gürel, F. \& Özcan, M. ( 2018). Ilkokul hayat bilgisi 3. Ankata: MEB. 
Davies, L. C. \& McKelvey, R. S. (1998). Emotional and behavioural problems and competencies among immigrant and non-immigrant adolescents. Australian and New Zealand Journal of Psychiatry, 32, 658-665, doi:10.3109/00048679809113120

Demir, E. (2018). ilkokul hayat bilgisi 1, Ankara: Kök.

Dubey, S. \& Mallah, V. (2015): Migration: causes and effects. The Business \& Management Review, 5(4).

Emin, M. N. (2018). Türkiye'deki Suriyeli çocukların devlet okullarında karşılaştığı sorunlar ankara ili örneği. Yıldırım Beyazıt Üniversitesi Sosyal Bilimler Enstitüsü Unpunlished Master Thesis.

Erol, M. \& Ersever, O. G. (2014), Göç krizi ve göç krizine müdahale. Kara Harp Okulu Bilim Dergisi, 24(1), 47-68.

Fitchett, P. G., \& Heafner, T. L. (2010). A national perspective on the effects of highstakes testing and standardization on elementary social studies marginalization. Theory \& Research in Social Education, 38(1), 114-130. doi: 10.1080/00933104.2010.10473418

Garrett, K.E. (Ed.) (2006). Living in America: Challenges facing new immigrants and refugees. Princeton, N.J: Robert Wood Johnson Foundation.

Göç İdaresi (2019). http://www.goc.gov.tr/icerik3/gecici-koruma_363_378_4713

Gür, N. (2017). Ülke deneyimleri ışığında uluslararası göç ekonomisi. SETA Yayınları.

Hall, E. \& Cuellar, N. G. (2016) "Immigrant health in the united states: a trajectory toward change". Journal of Transcultural Nursing, 27(6) 611-626.

Hintermann, C. (2009) Migration and memory in Austria: representations of migrations in a reluctant Immigration country. Finnish Journal of Ethnicity and Migration, 4(2), 4-16.

Hunter, L.M., (2005). Migration and environmental hazards. Population Environment, 26, 273-302.

International Organization for Migration (IOM) (2018). World migratıon report 2018, Geneva: IOM. Available from https://publications.iom.int/system/files/pdf/ wmr_2018_en.pdf

International Organization for Migration (IOM) (2013). International migration, health and human rights. Geneva: IOM. Available from: https://www.ohchr.org/Documents/Issues/Migration/WHO_IOM_UNOHCHRPublication.pdf

IOM (2009). Göç terimleri sözlüğü. Retrieved from: http://goc. gov.tr/files/files/goc_terimleri_sozlugu(1).pdf

Kaushik, V. \& Drolet, J. (2018). Settlement and integration needs of skilled immigrants in Canada. Social Sciences, 7(76), 1-14.

Kirmayer L.J, Narasiah L, Munoz M, Rashid M,Ryder AG, Guzder J, Hassan G, Rousseau C, \& Pottie K. (2011). Common mental health problems in immigrants and refugees: general approach in primary care. Can Med Assoc J.,183(12), E959-E967. doi: 10.1503/ cmaj.090292.
Koçak, Y. \& Terzi, E. (2012). Türkiye'de göç olgusu, göç edenlerin kentlere olan etkileri ve çözüm önerileri. Kafkas Üniversitesi iktisadi ve Idari Bilimler Fakültesi Dergisi, 3(3), 163-184.

Kuşkaya, Ç. (2018). Illkokul hayat bilgisi 2. Ankara: İpekyolu.

Kyaing-Kyaing, T. (2013). Pull and push factors of migration: a case study in the urban area of monywa township, Myanmar. Lecturer in the Department of Statistics at the Institute of Economics in Monywa, Myanmar. Available from: http://www.goftavard.gq.

Landale, N. S., Thomas, K.J.A. \& Van Hook. J. (2011). The living arrangements of children of Immigrants. Future of Children, 21,43-70

Leeman, Y. \& Ledoux, G. (2003). Intercultural education in dutch schools. Curriculum Inquiry, 33(4), 385- 399.

López, G., Bialik, K., \& Radford, J. (2018). Key findings about U.S. immigrants. Pew Research Center. Retrieved from: https://www.pewresearch.org/facttank/2018/11/30/key-findings-about-u-s-immigrants/

Lundquist, J. H. \& Massey, D. S. (2005). Politics or economics? International migration during the Nicaraguan Contra War. Journal of Latin American Studies, 37, 29-53.

MEBa. (2018). Hayat bilgisi öğretim programı 1-3. Retrieved from: http://mufredat.meb.gov.tr/Dosyalar/2018122171428547-HAYAT\%20B\%C4\%OLG\%C 4\%B0S\%C4\%B0\%C3\%96\%C4\%9ERET\%C4\%BOM\%20 PROGRAMI.pdf

Mood, C., Jonsson, J. O. \& Brolin Låftman, S. (2016). Immigrant integration and youth mental health in four European countries. European Sociological Review, 32(6), 716-729

Morrice, L. Shan, H. \& Sprung, A. (2017). Migration, adult education and learning. Studies in the Education of Adults, 49(2), 129-135.

Naz, Y. (2015). Türkiye'nin uluslar arası göç politikası ve uluslar arası göçün Türkiye'deki güncel sorunları. Unpunlished Master Thesis, Süleyman Demirel Üniversitesi.

Ohio Department of Education (2017). Ohio's learning standards: Social Studies (OLSSS). Retrieved from http:// education.ohio.gov/getattachment/Topics/Learning-in-Ohio/Social-Studies/Ohio-s-Learning-Standards-for-Social-Studies/SS-Standards.pdf.aspx?lang=en-US

Ojeda, L., Flores, L. Y., Rosales, R. \& Morales, A. (2011). Culturally competent qualitative research with Latino immigrants. Hispanic Journal of Behavioral Sciences, 33, 184-203. doi:10.1177/0739986311402626

Patton M.Q. (2014). Nitel araştırma ve değerlendirme yöntemleri. (M. Bütün, S. B. Demir Çev.). Ankara: Pegem.

Portes, A. \& Rivas, A. (2011). The adaptation of migrant children. Future of Children, 21(1), 219-246.

Rubinstein-Avila, E. (2017) Immigration and education: what should k-12 teachers, school administrators, and staff know?, the clearing house: a journal of educational strategies, Issues and Ideas, 90(1), 12-17. 
Skeldon, R. (1997). Migration and development. England: Longman.

Soysal, Y. N. (2005) 'Projections of Identity in French and German History and Civics Textbooks', in Hanna Schissler \& Yasemin Nuhoğlu Soysal (eds.) The nation, Europe, and the world: textbooks and curricula in transition. New York: Berghahn Books.

Stodolska, M. (2008). Adaptation processes among young immigrants: An integrative review. Journal of $I \mathrm{mmi}$ grant and Refugee Studies, 6(1), 34-59. https://doi. org/10.1080/15362940802119203

Suarez-Orozco, C. \& Suarez-Orozco, M.M. (2001). Children of immigraiton. Cambridge, MA: Harvard University Press.

Şahin, C. (2001).“Yurt dışı göçün bireyin psikolojik sağlığı üzerindeki etkisine ilişkin kuramsal bir inceleme". G.Ü. Gazi Eğitim Fakültesi Dergisi, 21(2), 57-67.

Taş, Y. \& Özcan, S. (2013). Türkiye'de iç göçün yoksulluğa ve istihdama etkileri. International Conference on Eurasian Economies. Session 1B: Büyüme ve Gelişme, 289- 298, Petersburg, Russia.

Tienda M. \& Haskins, R. (2011). Immigrant children: Introducing the Issue. The Future of Children. 21, 3-18.

Türnüklü, A. (2000). Eğitim bilim araştırmalarında etkin olarak kullanılabilecek nitel araştırma tekniği: görüşme. Kuram ve Uygulamada Eğitim Yönetimi, 24, 543-559

United Nations (2015). Trends in International immigrant stock: migrants by destination and origin, Department of Economic and Social Affairs, Available from: http:// www.un.org/en/development/desa/population/migration/data/estimates2/estimates15html

Van Ausfale, D., \& Feagin, J. R. (2001). The First R: How children learn race and racism. Lanham, MD: Rowman \& Littlefield

Worbs, S. (2003). The second generation in Germany: between school and labor market. The International Migration Review, 37(04), 1011-1038.

Yıldııım, A. \& Şimşek, H. (2013). Sosyal bilimlerde nitel araştırma yöntemleri. Ankara: Seçkin

Yılmaz, A. (2014). "Uluslararası göç: çeşitleri,nedenleri ve etkileri". Turkish Studies- International Periodical for the Languages, Literature and History of Turkish or Turkic, 9(2), 1685-1704

Zimmerman, C., Kiss, L., \& Hossain, M. (2011). Migration and health: a framework for 21st century policy-making. PLOS Medicine, 8(5), e1001034. 